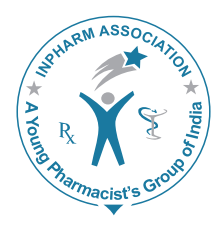

\title{
An in vitro study on the anti-microbial efficacy of ten herbal extracts on primary plaque colonizers
}

\author{
Byalakere Rudraiah Chandrashekar ${ }^{1 *}$, Ramesh Nagarajappa², Rupal Singh ${ }^{3}$, \\ Roopesh Thakur ${ }^{3}$
}

\author{
${ }^{1}$ Ph.D Scholar, Faculty of Dental Sciences, Pacifi c Academy of Higher Education and Research University, \\ Udaipur, Rajasthan, India, ${ }^{2}$ Department of Public Health Dentistry, Rama Dental College, Khanpur, \\ Uttar Pradesh, India, ${ }^{3}$ Center for Scientific Research and Development, People's University, Bhanpur, \\ Bhopal, Madhya Pradesh, India
}

\begin{abstract}
Introduction: To assess and compare the anti-microbial efficacy of ten herbal extracts against primary plaque colonizers. Materials and Methods: The branches of 10 plants with ethno-pharmacological background were collected and healthy leaves separated to prepare the fine powder. The extraction procedure was carried out by cold infusion method using ethanol. The working concentration of the extract $(100 \mathrm{mg} / \mathrm{ml})$ was prepared by mixing dried leaf extract with dimethyl sulfoxide (DMSO). $0.2 \%$ chlorhexidine and DMSO were used as positive and negative controls, respectively. Agar well diffusion method was used for anti-microbial efficacy testing. The statistical analysis was done using SPSS 16 . The mean diameter of inhibition zone between the categories was compared using one-way analysis of variance and Tukey's post-hoc test. Results: The highest mean diameter of inhibition zone against Streptococcus mutans was produced by Acacia nilotica followed by Psidium guajava, Eucalyptus hybrid and Murraya koenigii L.S extracts in the descending order. The highest mean inhibition zone against Streptococcus sanguinis was produced by chlorhexidine followed by A. nilotica, Eucalyptus, P. guajava, and M. koenigii L.S extracts in the descending order. The highest mean inhibition zone against Streptococcus salivarius was produced by P. guajava, followed by chlorhexidine, A. nilotica, Eucalyptus, M. koenigii L.S and Hibiscus sabdariffa $L$ extracts in the descending order. Conclusion: $P$. guajava, Eucalyptus, A. nilotica, M. koenigii L.S and $H$. sabdariffa $L$ have the potential to inhibit primary plaque colonizers, and they could be used as anti-plaque agents.
\end{abstract}

Key words: Acacia nilotica, Eucalyptus hybrid, Murraya koenigii L. sprengel, Psidium guajava, Streptococcus mutans, Streptococcus salivarius, Streptococcus sanguis

\section{INTRODUCTION}

\begin{tabular}{|c|l|}
\hline \multicolumn{2}{|c|}{ Access this article online } \\
\hline \multirow{2}{*}{ Journal Sponsor } & \multicolumn{1}{|l|}{$\begin{array}{l}\text { Website: } \\
\text { www.jyoungpharm.org }\end{array}$} \\
\hline \multirow{2}{*}{ www.phcog net } & $\begin{array}{l}\text { DOI: } \\
\text { Do.5530/jyp.2014.4.6 }\end{array}$ \\
& \\
\hline
\end{tabular}

Oral health is an inseparable part of general health. Oral health has an impact on general health and well-being as the oral diseases cause pain and suffering, alter the eating pattern, speech, and affect the quality of life as a whole. Oral health also has an effect on other chronic diseases. Oral diseases are one among the most common chronic diseases affecting mankind. In view of their high

\footnotetext{
*Address for correspondence:

Dr. Byalakere Rudraiah Chandrashekar, Faculty of Dental Sciences, Pacific Academy of Higher Education and Research University, Udaipur-313 003, Rajasthan, India.E-mail: drchandrubr@yahoo.com
} 
prevalence, the impact on individual, family, and society as a whole as well as the high cost of treating them, oral diseases are considered an important public health problem. The literature suggests oral diseases to be the fourth most expensive diseases to treat in some countries. ${ }^{1}$

Although the World Health Organization report indicates a decline in the dental caries prevalence in most developed countries in the recent times, it can still be considered a major public health problem in many developing countries as the disease affects $60-90 \%$ of their school going children. ${ }^{2}$ Loss of teeth due to periodontitis often causes discomfort, compromises the esthetics and function. Moreover, the recent studies suggest an association between chronic low-grade infections like periodontitis with systemic health problems ${ }^{3}$ including cardiovascular diseases, pre-term low birth weight, diabetes mellitus, and chronic obstructive pulmonary disease. ${ }^{3}$ The treatment of established dental diseases is very expensive and can never be considered an option for the poor. The literature indicates that the cost of treating dental caries alone which is estimated at US\$3513/1000 children may exceed the total health budget for children in the majority of the low-income countries. ${ }^{1}$ There is an immediate need for promoting preventive measures that are acceptable, costeffective, and easily available. The robust, effective, feasible, and innovative strategies need to be evolved to combat these diseases.

The practices established for the prevention of dental caries and periodontal diseases are use of fluorides in various forms and mechanical oral hygiene along with proper professional care respectively. In reality, however, the motivation and dexterity anticipated for optimum oral hygiene are beyond the ability of the majority of the population especially in developing countries owing to the low priority given to oral health. Anti-microbial mouth rinses have also been recommended as adjuncts to mechanical plaque control methods. The most commonly used anti-plaque agent is chlorhexidine gluconate. The use of chlorhexidine, however, has some established side effects such as alteration in taste sensation, staining of teeth, and development of resistant microorganisms which debilitate their long term use. ${ }^{4}$ There exists a need to develop some innovative strategies that act against both dental caries and periodontal diseases simultaneously. One such innovation would be to explore the anti-bacterial potential of medicinal plants that have some ethnopharmacological background on dental caries and plaque bacteria. The need for an herbal alternative that can inhibit both dental caries and plaque microorganisms led us to undertake the present study to assess and compare the anti-microbial efficacy of 10 herbal extracts against primary plaque colonizers.

\section{MATERIALS AND METHODS}

\section{Plant material}

This was an in vitro study conducted over a period of 6 months from July to December 2013 at the research laboratory, Center for Scientific Research and Development, People's University, Bhopal. The branches of ten plants with ethno-pharmacological background which are easily available in central India were collected from the surrounding areas. The plants were identified and authenticated by a taxonomist. The branches were thoroughly washed in running water and then the healthy leaves were separated from these branches. The leaves were again rinsed in water treated with reverse osmosis and shade-dried over a period of 3-4 weeks at room temperature. The dried leaves were hand-crushed separately to obtain coarse powder of the 10 leaves. Subsequently, the fine powder was prepared using a mixer grinder and stored in airtight plastic bottles. The bottles were labeled and stored in the refrigerator at $4^{\circ} \mathrm{C}$ till further use.

\section{Preparation of the herbal extracts using cold infusion method}

Ethanol was used as a solvent for the extraction process in the present study. Two g of fine powder was weighed into a bottle and mixed with $10 \mathrm{ml}$ of ethanol. The mixture was subjected to gentle and intermittent stirring for $15 \mathrm{~min}$ every $2 \mathrm{~h}$ for $48 \mathrm{~h}$ on a rotary shaker. The mixture was then filtered using Whatman filter paper. The filtrate was allowed to dry completely. The weight difference between the empty bottle and the bottle containing extract was used to determine the yield of each herbal extract. The dried leaf extract was mixed with the required quantity of dimethyl sulfoxide (DMSO) to obtain the working concentration of the extract $(100 \mathrm{mg} / \mathrm{ml})$.

\section{Anti-microbial efficacy testing}

\section{Bacterial strains}

The American Type Culture Collection (ATCC) strains of three primary plaque colonizers viz., Streptococcus mutans (ATCC), Streptococcus sanguis (ATCC) and Streptococcus salivarius (ATCC) were imported from USA and revived at the research laboratory for further microbiological assay. The three bacterial cultures were maintained on brain heart infusion agar slants with periodical subculturing and stored at $4^{\circ} \mathrm{C}$.

Journal of Young Pharmacists Vol 6 • Issue 4 • Oct-Dec 2014 
The anti-microbial efficacy of the 10 herbal extracts at $10 \%$ concentration ( $50 \mu \mathrm{l}$ volume) was assessed using agar well diffusion method. The diameter of the inhibition zone was measured at three different planes on the under surface of the agar plate using a transparent scale. $0.2 \%$ chlorhexidine was used as a positive control while DMSO acted as a negative control. The anti-microbial efficacy testing on these bacteria was done in duplicate, and the mean diameter of inhibition zones for each extract against the bacteria was computed.

\section{Data entry and statistical analysis}

The data were entered onto a personal computer, and statistical analysis was done using SPSS version 20 (IBM, Chicago, USA). The diameter of the inhibition zone against bacteria was expressed as mean and standard deviation (SD). The mean diameter of inhibition zone between different categories was compared using one-way analysis of variance (ANOVA). Tukey's post hoc test was used for multiple pairwise comparisons wherever ANOVA yielded a significant result. The statistical significance was fixed at 0.05 .

\section{RESULTS}

The details of the 10 plant extracts used in the present study, their yield using ethanol as solvent and cold infusion method for the extraction process is denoted in Table 1. The details of bacteria used for anti-microbial efficacy testing are denoted in Table 2.

\section{S. mutans}

The extracts of Aradiractha indica, Hibiscus sabdariffa L, Acacia nilotica, Psidium Guajava, Eucalyptus hybrid and Murraya koenigii L. sprengel inhibited the growth of S. mutans while extracts of Magnifera indica, Ocimum sanctum Linn, Rosa rubiginosa and Aloe barbadensis failed to inhibit the growth. The extracts of $A$. nilotica produced the highest zone of inhibition $(21.83 \mathrm{~mm} \pm 0.41$, mean $\pm \mathrm{SD})$ followed by P. guajava (21.17 $\mathrm{mm} \pm 1.08$ ), Eucalyptus hybrid $(20.83 \pm 1.08)$, M. koenigii L.S $(9.75 \pm 1.17)$, H. sabdariffa $\mathrm{L}$ (7.42 \pm 0.20$)$ and $A$. indica (7.25 \pm 0.28$)$. The mean zone of inhibition produced by chlorhexidine (positive control) was $14.25 \mathrm{~mm}(0.52)$ while DMSO failed to inhibit the growth of $S$. mutans. The difference in the mean zone of inhibition between the various groups was statistically significant $(P=0.001$, Table 3$)$. The multiple pair-wise comparisons revealed that the extracts of $A$. nilotica, $P$. guajava, and Eucalyptus hybrid produced a significantly higher zone of inhibition compared to chlorhexidine, while the extracts of $M$. koenigii L. sprengel and $H$. sabdariffa produced lesser zone of inhibition $(P=0.001$, Table 4$)$.

\section{S. sanguis}

The extracts of $A$. nilotica $(21.33 \pm 0.26)$, Eucalyptus hybrid (19.17 \pm 0.82$)$, P. guajava (18.58 \pm 0.59$)$, M. koenigii L.S $(10.42 \pm 0.92)$, and $H$. sabdariffa L (6.50 \pm 0.63$)$ inhibited the growth of S. sanguis. The extracts of $A$. indica, M. indica, $O$. sanctum Linn, $R$. rubiginosa, and $A$. barbadensis along with DMSO failed to inhibit the growth of $S$. sanguis. However, chlorhexidine $(21.83 \pm 0.61)$ produced significantly higher inhibition zone compared to all the plant extracts $(P=0.001$, Table 4) except $A$. nilotica which produced almost similar efficacy.

\section{S. salivarius}

Among the various effective plant extracts against $S$. salivarius, P. Guajava $(23.00 \pm 0.48)$ produced the highest zone of inhibition followed by $A$. nilotica $(21.17 \pm 1.1)$, Eucalyptus hybrid (20.00 \pm 0.45$)$, M. koenigii L.S (13.25 \pm 0.69$)$, and $H$. sabdariffa $\mathrm{L}$ extract $(9.75 \pm 0.27)$. The extracts derived from the leaves of $A$. indica, $M$. indica, O. sanctum Linn, R. rubiginosa, and $A$. barbadensis as well as DMSO failed to

Table 1: The plant profile and yield of the ten herbal extracts assessed in the present study

\begin{tabular}{lllcc}
\hline Plant name & Botanical name & Family & Weight of dried extract (g) & Yield (\%) \\
\hline Neem & A. indica & Meliaceae & 0.053 & 0.139 \\
Guava & P. guajava & Myrataceae & 0.198 \\
Eucalyptus & Eucalyptus hybrid & Myrataceae & & \\
& (E. canaldulensis $\times$ E. ovate) & & 0.95 \\
Babul & A. nilotica & Leguminosae & 0.091 & 9.9 \\
Curry & M. koenigii L.S & Rutaceae & 0.101 & 4.55 \\
Rose & R. rubiginosa & Rosaceae & 0.079 & 5.05 \\
Hibiscus & H. sabdariffa L & Malvaceae & 0.104 & 3.95 \\
Mango & M. indica & Anacardaceae & 0.047 & 5.2 \\
Tulsi & O. sanctum Linn & Lamiaceae & 0.017 & 0.011 \\
Aloe vera & A. barbadensis & Asphodelaceae & 0.011 \\
\hline
\end{tabular}

A. indica: Azadiractha indica, P. guajava: Psidium guajava, E. canaldulensis: Eucalyptus canaldulensis, E. ovate: Eucalyptus ovate, A. nilotica: Acacia nilotica, M. koenigii L.S: Muraya koenigii L. Sprengel, R. rubiginosa: Rosa rubiginosa, H. sabdariffa L: Hibiscus sabdariffa L, M. indica: Magnifera indica, O. sanctum Linn: Ocimum sanctum Linn, A. barbadensis: Aloe barbadensis, A. vera: Aloe vera 
Table 2: Details of the bacteria used for antimicrobial efficacy testing

\begin{tabular}{|c|c|c|c|c|}
\hline Bacteria & $\begin{array}{l}\text { ATCC } \\
\text { Number }\end{array}$ & $\begin{array}{l}\text { Selective media } \\
\text { used for revival }\end{array}$ & $\begin{array}{l}\text { Type of } \\
\text { hemolysis } \\
\text { on blood } \\
\text { agar plate }\end{array}$ & $\begin{array}{l}\text { Media for } \\
\text { antimicrobial } \\
\text { efficacy } \\
\text { testing }\end{array}$ \\
\hline S. mutans & 25175 & $\begin{array}{l}\text { Brain heart } \\
\text { infusion agar with } \\
5 \% \text { sheep blood }\end{array}$ & $\begin{array}{l}\text { Gamma } \\
\text { hemolysis }\end{array}$ & $\begin{array}{l}\text { Brain heart } \\
\text { infusion agar }\end{array}$ \\
\hline S. sanguis & 10556 & $\begin{array}{l}\text { Brain heart } \\
\text { infusion agar with } \\
5 \% \text { sheep blood }\end{array}$ & $\begin{array}{l}\text { Alpha } \\
\text { hemolysis }\end{array}$ & $\begin{array}{l}\text { Brain heart } \\
\text { infusion agar }\end{array}$ \\
\hline S. salivarius & 13419 & $\begin{array}{l}\text { Brain heart } \\
\text { infusion agar with } \\
5 \% \text { sheep blood }\end{array}$ & $\begin{array}{l}\text { Gamma } \\
\text { haemolysis }\end{array}$ & $\begin{array}{l}\text { Brain heart } \\
\text { infusion agar }\end{array}$ \\
\hline
\end{tabular}

ATCC: American Type Culture Collection, S. mutans: Streptococcus mutans,

S. sanguis: Streptococcus sanguinis, S. salivarius: Streptococcus salivarius

Table 3: Antimicrobial efficacy of various herbal extracts on S. mutans, S. sanguis and S. salivarius

\begin{tabular}{lccc}
\hline Herbal extract & \multicolumn{3}{c}{ Mean diameter of inhibition zone in } \\
& mm (SD) \\
\cline { 2 - 4 } & S. mutans & S. sanguis & S. salivarius \\
\hline A. indica & $7.25(0.28)$ & No activity & No activity \\
P. guajava & $21.17(1.08)$ & $18.58(0.59)$ & $23.00(0.48)$ \\
Eucalyptus hybrid & $20.83(1.08)$ & $19.17(0.82)$ & $20.00(0.45)$ \\
(E. canaldulensis $\times$ & & & \\
E. ovate) & & & \\
A. nilotica & $21.83(0.41)$ & $21.33(0.26)$ & $21.17(1.1)$ \\
M. koenigii L.S & $9.75(1.17)$ & $10.42(0.92)$ & $13.25(0.69)$ \\
R. rubiginosa & No activity & No activity & No activity \\
H. sabdariffa L & $7.42(0.20)$ & $6.50(0.63)$ & $9.75(0.27)$ \\
M. indica & No activity & No activity & No activity \\
O. sanctum Linn & No activity & No activity & No activity \\
A. barbadensis & No activity & No activity & No activity \\
0.2\% Chlorhexidine & $14.25(0.52)$ & $21.83(0.61)$ & $22.08(0.38)$ \\
DMSO & No activity & No activity & No activity \\
Statistical & $F$ value: & $F$ value: & $F$ value: \\
inference & 1363.69 & 2433.569 & 3037.169 \\
& df: 11 & df: 11 & df: 11 \\
& $P$ value: 0.001 & $P$ value: 0.001 & $P$ value: 0.001 \\
\hline
\end{tabular}

S. mutans: Streptococcus mutans, S. sanguis: Streptococcus sanguinis, S. salivarius: Streptococcus salivarius, A. indica: Azadiractha indica, P. guajava: Psidium guajava, E. canaldulensis: Eucalyptus canaldulensis, E. ovate: Eucalyptus ovate, A. nilotica: Acacia nilotica, M. koenigii L.S: Muraya koenigii L. Sprengel, R. rubiginosa: Rosa rubiginosa, H. sabdariffa L: Hibiscus sabdariffa L, M. indica: Magnifera indica, O. sanctum Linn: Ocimum sanctum Linn, A. barbadensis: Aloe barbadensis, DMSO: Dimethyl sulfoxide, SD: Standard deviation

inhibit the growth of $S$. salivarius. Although a significant difference in the mean diameter of inhibition zone was noted between various categories, the multiple pair-wise comparisons revealed that the extracts of P. guajava produced a significantly higher zone of inhibition against S. salivarius compared chlorhexidine and other extracts $(P=0.001$, Table 4). The mean diameter of inhibition zone produced by chlorhexidine was $22.08 \pm 0.38$ ).

It can be inferred from the above results that the leaf extracts derived from A. nilotica, P. guajava, Eucalyptus hybrid, and M. koenigii L.S possess anti-microbial efficacy
Table 4: Multiple pair-wise comparisons between different categories on antimicrobial efficacy against S. mutans, S. sanguis, and $S$. salivarius

\begin{tabular}{|c|c|c|c|}
\hline \multirow{2}{*}{$\begin{array}{l}\text { Herbal } \\
\text { extract* }\end{array}$} & \multicolumn{3}{|c|}{ Mean diameter of inhibition zone in $\mathrm{mm}$ (SD) } \\
\hline & S. mutans & S. sanguis & S. salivarius \\
\hline$A$ versus $B$ & 0.001 & 0.001 & 0.001 \\
\hline$A$ versus $C$ & 0.001 & 0.001 & 0.001 \\
\hline$A$ versus $D$ & 0.001 & 0.001 & 0.001 \\
\hline$A$ versus $E$ & 0.001 & 0.001 & 0.001 \\
\hline$A$ versus $F$ & 1.000 & 0.001 & 0.001 \\
\hline A versus $G$ & 0.001 & 0.001 & 0.001 \\
\hline A versus $H$ & 0.001 & 1.000 & 1.000 \\
\hline$B$ versus $C$ & 0.998 & 0.600 & 0.001 \\
\hline$B$ versus $D$ & 0.732 & 0.001 & 0.001 \\
\hline$B$ versus $E$ & 0.001 & 0.001 & 0.001 \\
\hline$B$ versus $F$ & 0.001 & 0.001 & 0.001 \\
\hline$B$ versus $G$ & 0.001 & 0.001 & 0.037 \\
\hline$B$ versus $H$ & 0.001 & 0.001 & 0.001 \\
\hline$C$ versus $D$ & 0.166 & 0.001 & 0.002 \\
\hline$C$ versus $E$ & 0.001 & 0.001 & 0.001 \\
\hline$C$ versus $F$ & 0.001 & 0.001 & 0.001 \\
\hline$C$ versus $G$ & 0.001 & 0.001 & 0.001 \\
\hline $\mathrm{C}$ versus $\mathrm{H}$ & 0.001 & 0.001 & 0.001 \\
\hline$D$ versus $E$ & 0.001 & 0.001 & 0.001 \\
\hline$D$ versus $F$ & 0.001 & 0.001 & 0.001 \\
\hline$D$ versus $G$ & 0.001 & 0.794 & 0.037 \\
\hline$D$ versus $H$ & 0.001 & 0.001 & 0.001 \\
\hline$E$ versus $F$ & 0.001 & 0.001 & 0.001 \\
\hline E versus $G$ & 0.001 & 0.001 & 0.001 \\
\hline E versus $H$ & 0.001 & 0.001 & 0.001 \\
\hline$F$ versus $G$ & 0.001 & 0.001 & 0.001 \\
\hline $\mathrm{F}$ versus $\mathrm{H}$ & 0.001 & 0.001 & 0.001 \\
\hline G versus $H$ & 0.001 & 0.001 & 0.001 \\
\hline
\end{tabular}

A: Azadiractha indica, B: Psidium guajava, C: Eucalyptus hybrid, D: Acacia nilotica, E: Murraya koenigii L. Sprengel, F: Hibiscus sabdariffa L,

G: $0.2 \%$ chlorhexidine, $\mathrm{H}$ : Dimethyl sulfoxide, $\mathrm{S}$. mutans: Streptococcus mutans, S. sanguis: Streptococcus sanguinis, S. salivarius: Streptococcus salivarius, SD: Standard deviation

against all these bacteria. The inhibitory effect of $P$. guajava, A. nilotica, and Eucalyptus hybrid extracts on $S$. mutans were significantly higher than that produced by chlorhexidine.

\section{DISCUSSION}

The increasing trends in dental caries and gingival periodontal diseases among the population in developing countries, the increasing costs of treating these diseases, and the potential side effects associated with conventional anti-plaque agents call for alternate strategies. The extracts derived from medicinal plants are staging a comeback, and herbal "renaissance" is occurring all over the globe. The plant medicines, now a day, symbolize safety, in contrast to the synthetics that are shown to be unsafe to humans and the environment to some extent. Plant medicines are the foremost remedial agents used in traditional medicine for 
several 1000 years. The literature demonstrates that around 2500 plant species have been used by traditional healers in India and 100 of these are used as regular sources of medicine. The last few decades have witnessed a surge in the research concerning the traditional use, and efficacy of medicinal plants in different parts of the world. ${ }^{5}$ The extracts of medicinal plants have been shown to possess anti-plaque, anti-oxidant, anti-bacterial, anti-fungal, antiviral, anti-inflammatory, and analgesic effects. The present study was undertaken to screen ten plant extracts that are easily available in central India for their anti-microbial efficacy against three bacteria that are regarded as primary plaque colonizers.

The extract of $A$. indica has been found to possess antimicrobial and anti-viral properties. ${ }^{6}$ Prashant $e t$ al. ${ }^{7}$ (2007) found that the extracts derived from the twigs of $A$. indica inhibited S. mutans, S. sanguis, and S. salivarius. The mean diameter of the inhibition zone produced against these bacteria at $10 \%$ concentration at the end of $24 \mathrm{~h}$ was $1.1 \mathrm{~mm}, 1.0 \mathrm{~mm}$, and $0.8 \mathrm{~mm}$ respectively. The mean diameter of the inhibition zone by the leaf extract of A. indica against $S$. mutans was much higher in our study compared to these results. The anti-microbial efficacy of extracts derived from $A$. indica could be attributed to the presence of alkaloid margosine, resins, tannins, oils, saponins, flavonoids, sterols, gum, chloride, fluoride, silica, sulfur, and calcium. ${ }^{8}$ However, the leaf extract of $A$. indica in our study failed to inhibit $S$. sanguis and S. salivarius. The difference in the part of the plant, the bacterial strains, the solvent, and the extraction process employed for antimicrobial efficacy testing may explain these differences observed in our study and others.

The leaf of P. guajava has been widely used in the management of gastroenteritis and child diarrhea by the rural folk who cannot afford antibiotics. The leaf extracts of P. guajava inhibited the growth of all the three bacteria in our study, and its efficacy was comparable to chlorhexidine. The anti-microbial efficacy of $P$. guajava leaf extract could be due to the presence of guajaverin, essential oil constituents (monoterpenes, 1.8-cineol, $\varrho$-cimen, and acetate of $\alpha$-terpenil), and psidiolic acid. ${ }^{9}$ Hema et al. (2009) ${ }^{10}$ in their study found $P$. guajava to be effective against Pseudomonas lundensis, Aspergillus niger, and Aspergillus flavus. Gonçalves et al. (2008) ${ }^{11}$ found the essential oils, methanol, hexane, ethyl acetate extracts of $P$. guajava leaves to be effective against Staphylococcus aureus, Salmonella spp. and Escherichia coli. Hence, the extract could be considered important potential sources for antimicrobial compounds. Ismail et al. (2012) ${ }^{12}$ in their study found Guava to be effective against $S$. aureus, and E. coli.
Our study demonstrated the anti-microbial efficacy of the leaf extracts of $P$. guajava against primary plaque colonizers similar to these studies. However, we could not compare our findings with other studies as this study is the first of its kind assessing the anti-microbial efficacy of P. guajava leaf extract on oral bacteria.

Eucalyptus was found to inhibit all the three bacteria in our study, and the mean inhibition zone was comparable to chlorhexidine. Nagata et al. $(2006)^{13}$ demonstrated antibacterial activity of macrocarpals which are phloroglucinol derivatives from Eucalyptus leaves against periodontopathic bacteria. Porphyromonas gingivalis exhibited the highest sensitivity to macrocarpals among the various tested bacteria. Takarada et al. $(2004)^{14}$ in their study found the leaf extracts of Eucalyptus to be effective against $S$. mutans, Streptococcus sobrinus, Actinobacillus actinomycetemcomitans, P. gingivalis, and Fusobacterium nucleatum. The study also found that the Eucalyptus oil was successful in preventing the adhesion of $S$. mutans. The results of our study clearly demonstrated the usefulness of the leaf extract of Eucalyptus hybrid as an anti-bacterial agent similar to these studies.

A. nilotica exhibited an inhibitory effect against all the three bacteria tested in the present study. The inhibitory effect was comparable to chlorhexidine. Deshpande Kadam $(2013)^{15}$ found $A$. nilotica extracts to inhibit the growth of $S$. mutans (mean diameter of the inhibition zone was $31 \mathrm{~mm} \pm 0.7)$. An in vitro study by Dabur et al. $(2007)^{16}$ found the extracts of $A$. nilotica to possess anti-microbial and anti-fungal properties. Pai et al. $(2010)^{17}$ in their in vitro study found $A$. nilotica to be effective against Candida albicans. All these studies demonstrated the anti-microbial potential of $A$. nilotica against oral microbes similar to the findings in our study. The anti-microbial potential of $A$. nilotica could be due to the presence of tannins, alkaloids, flavonoids, saponins, anthraquinones, and cardiac glycosides. ${ }^{18}$

M. koenigii L. used as a spice for its characteristic flavor and aroma is an important herb of Indian Origin. This herb has been extensively used for centuries in Ayurvedic medicine. ${ }^{19,20}$ The herb is reported to possess a variety of medicinal benefits that include stimulant, anti-microbial, anti-diabetic, anti-oxidant, anti-dysenteric, anti-carcinogenic properties. The carbazole alkaloids, $\mathrm{b}$-carotene, tocopherol, and lutein in $M$. koenigii $\mathrm{L}$. are reported to possess anti-microbial properties. ${ }^{19}$ The leaf extract of $M$. koenigii $\mathrm{L}$. in our study inhibited all the three bacteria thus, demonstrating the anti-bacterial efficacy similar to these studies. However, the mean diameter of 
the inhibition zone produced by the plant extract was significantly lesser than chlorhexidine. Ningappa et al. $(2010)^{19}$ found $M$. koenigii to exhibit a broad spectrum of anti-bacterial activity against human pathogenic bacteria, which was as good as commercial antibiotics. The authors recommended the extracts of $M$. koenigii $\mathrm{L}$. to be a nontoxic, anti-oxidant antibiotic. Sunitha et al. (2012) ${ }^{21}$ found the alcoholic extracts of $M$. koenigii $\mathrm{L}$. to exhibit the antibacterial activity on dental caries bacteria. Ramesh et al. $(2012)^{22}$ found the chewing of curry leaves to increase the salivary $\mathrm{pH}$. The authors concluded that the plant extract could be used as home remedy as it creates an oral environment that is unfavorable for microbes. The results of our study and all the studies cited demonstrate that the leaf extract of $M$. koenigii L. could be tried as a potential anti-microbial agent that is effective against dental caries and plaque microorganisms.

H. sabdariffa L leaf extract inhibited the growth of all the three bacteria in the present study. However, the mean inhibition zone was significantly less compared to chlorhexidine. The anti-bacterial activity could be attributed to the presence of biterpenoids, alkaloids, phenolics, and flavonoids. Fullerton et al. (2011) ${ }^{23}$ found the extracts of H. sabdariffa to be effective against E. coli and concluded that the extract proved to be a promising anti-microbial agent. Nagarajappa et al. (2013) ${ }^{24}$ in their in vitro study found the leaves of Hibiscus rosa-sinensis to inhibit the growth of S. mutans. These results were consistent with the findings of our study.

The extracts of O. sanctum Linn, M. indica, R. rubiginosa, A. barbadensis failed to inhibit the growth of S. mutans, S. sanguis and S. salivarius. Tulsi (O. sanctum), is the holiest and most sacred herbs grown in India. In view of its therapeutic benefits, it is known as the queen of herbs or mother medicine of nature. Agarwal et al. (2010) ${ }^{25}$ in their in vitro study found tulsi extract at $4 \%$ concentration to exhibit maximum anti-microbial efficacy against $S$. mutans $(18 \mathrm{~mm})$. The mean zone of inhibition at $10 \%$ concentration was $16 \mathrm{~mm}$. M. indica contains bitter gum, tannins, and resins. ${ }^{26}$ Prashant et al. (2007) ${ }^{7}$ found the twig extract of Mango to inhibit the growth of S. mutans, S. sanguis, and S. salivarius at $10 \%$ concentration. A. barbadensis Miller is widely used as a convenient home grown remedy in the management of burns and also possesses many other medicinal benefits. Two in vitro studies on the efficacy of Aloe vera extracts on oral bacteria involved in dental caries and periodontitis found the product to be effective. ${ }^{27,28}$ Kumar et al. (2012) ${ }^{29}$ found the leaf, stem, and root extracts of Rosa indica to be effective against two Gram-negative bacteria (E. coli, Pseudomonas aeruginosa) and two Gram-positive bacteria
(Bacillus licheniformis and S. aureus) The results of our study were contradictory to the findings of these studies. This contradiction in the efficacy of the extracts of $O$. sanctum Linn, M. indica, A. barbadensis and R. rubiginosa could be due to differences in the plant species, its part being used for extraction, the phytochemical constituents (that vary with the season, soil etc.), the extraction process, the bacteria, and the method of assessing the anti-microbial efficacy. The contradictory findings that may be due to differences in the phytochemical constituents of the herbal extracts in different regions highlight the need for mandatory and thorough investigation of plant extracts before their use in pharmacological industries.

\section{SUMMARY AND CONCLUSION}

The present study was undertaken to assess the antimicrobial efficacy of the leaf extracts of 10 plants that are easily available in Central India. The anti-microbial efficacy was assessed on three bacteria which are initial colonizers in the plaque formation. The study found the leaf extracts of P. guajava, Eucalyptus hybrid, A. nilotica, M. koenigii L.S and $H$. sabdariffa $\mathrm{L}$ to be effective against $S$. mutans, $S$. sanguis and $S$. salivarius. The mean inhibition zone produced by $P$. guajava, Eucalyptus hybrid, A. nilotica was comparable to $0.2 \%$ chlorhexidine. The mean diameter of the inhibition zone produced by M. koenigii L.S and H. sabdariffa L extracts was lesser in comparison to chlorhexidine. The leaf extract of $A$. indica though inhibited $S$. mutans, it failed to inhibit $S$. sanguis and S. salivarius. The leaf extracts of $M$. indica, $O$. sanctum Linn, R. rubiginosa, and $A$. barbadensis failed to inhibit the three bacteria at $10 \%$ concentration.

We can conclude from these results that the leaf extracts of P. guajava, Eucalyptus hybrid, A. nilotica, M. koenigii L.S, and $H$. sabdariffa $\mathrm{L}$ have the potential to inhibit primary plaque colonizers, and they could be used as anti-plaque agents. The in vitro nature of the study call for further research using these extracts. The present study was conducted using a working concentration of $100 \mathrm{mg} / \mathrm{ml}$. The use of higher concentrations may yield significantly higher benefits and the anti-microbial efficacy testing using clinical isolates of these bacteria may yield different results. These extracts could also be further tested against Lactobacillus acidophilus, secondary and tertiary plaque colonizers. The further studies using the combination of these plant extracts could yield a formulation that is either as effective as chlorhexidine or superior to it. The development of such an innovative formulation is the need of the hour as it could help in preventing two most common dental diseases afflicting mankind.

Journal of Young Pharmacists Vol 6 • Issue 4 • Oct-Dec 2014 


\section{REFERENCES}

1. Sheiham A. Oral health, general health and quality of life. Bull World Health Organ. 2005;83:644.

2. Petersen PE. The World Oral Health Report 2003: Continuous improvement of oral health in the $21^{\text {st }}$ century - The approach of the WHO Global Oral Health Programme. Community Dent Oral Epidemiol. 2003;31 Suppl 1:3-23.

3. Weidlich P, Cimões R, Pannuti CM, Oppermann RV. Association between periodontal diseases and systemic diseases. Braz Oral Res. 2008;22 Suppl 1:32-43.

4. Eley BM. Antibacterial agents in the control of supragingival plaque A review. Br Dent J. 1999;186:286-96.

5. Kumar G, Jalaluddin M, Rout P, Mohanty R, Dileep CL. Emerging trends of herbal care in dentistry. J Clin Diagn Res. 2013;7:1827-9.

6. Parida MM, Upadhyay C, Pandya G, Jana AM. Inhibitory potential of neem (Azadirachta indica Juss) leaves on dengue virus type-2 replication. J Ethnopharmacol. 2002;79:273-8.

7. Prashant GM, Chandu GN, Murulikrishna KS, Shafiulla MD. The effect of mango and neem extract on four organisms causing dental caries: Streptococcus mutans, Streptococcus salivavius, Streptococcus mitis, and Streptococcus sanguis: An in vitro study. Indian J Dent Res. 2007;18:148-51.

8. Akhtar MS, Ajmal M. Significance of chewing-sticks (miswaks) in oral hygiene from a pharmacological view-point. J Pak Med Assoc. 1981;31:89-95.

9. Andrade-Neto M, Alencar JW, Silveira ER, Cunha AN. Volatile constituents of Psidium poblianum Berg. and Psidium guyanensis Pers. J Essential Oils Res. 1994;6:299-300.

10. Hema R, Kumaravel S, Elanchezhiyan N. Antimicrobial activity of some of the South-Indian spices and herbals against food pathogens. Glob J Pharmacol. 2009;3:38-40.

11. Gonçalves FA, Andrade Neto M, Bezerra JN, Macrae A, Sousa OV, Fonteles-Filho AA, et al. Antibacterial activity of GUAVA, Psidium guajava Linnaeus, leaf extracts on diarrhea-causing enteric bacteria isolated from Seabob shrimp, Xiphopenaeus kroyeri (Heller). Rev Inst Med Trop Sao Paulo. 2008;50:11-5.

12. Ismail M, Minhas PS, Khanum F, Sahana VM, Sowmya C. Antibacterial activity of leaves extract of guava (Psidium guajava). Int J Res Pharm Biomed Sci. 2012;3:1-3.

13. Nagata H, Inagaki Y, Yamamoto Y, Maeda K, Kataoka K, Osawa K, et al. Inhibitory effects of macrocarpals on the biological activity of porphyromonas gingivalis and other periodontopathic bacteria. Oral Microbiol Immunol. 2006;21:159-63.

14. Takarada K, Kimizuka R, Takahashi N, Honma K, Okuda K, Kato T. A comparison of the antibacterial efficacies of essential oils against oral pathogens. Oral Microbiol Immunol. 2004;19:61-4.

15. Deshpande SN, Kadam DG. Phytochemical analysis and antibacterial activity of Acacia nilotica against Streptococcus mutans. Int J Pharm Pharm Sci. 2013;5:236-8.

16. Dabur R, Gupta A, Mandal TK, Singh DD, Bajpai V, Gurav AM, et al. Antimicrobial activity of some Indian medicinal plants. Afr J Tradit Complement Altern Med. 2007;4:313-8.

17. Pai MB, Prashanth GM, Murulikrishna KS, Shivakumar KM, Chandu GN. Antifungal efficacy of Punica granatum, Acacia nilotica, Cuminum ciminum and Foeniculum vulgare on Candida albicans: An In vitro study. Indian J Dent Res. 2010;21:334-6.

18. Tenguria M, Chand P, Upadhyay R. Estimation of total polyphenolic content in aqueous and methanolic extract from the bark of Acacia nilotica. Int J Pharmacol Sci Res. 2012;3:3458-61.

19. Ningappa MB, Dhananjaya BL, Dinesha R, Harsha R, Srinivas L. Potent antibacterial property of APC protein from curry leaves (Murraya koenigii L.). Food Chem. 2010;118:747-50.

20. Gupta P, Nahata A, Dixit VK. An update on Murraya koenigii spreng: A multifunctional Ayurvedic herb. Zhong Xi Yi Jie He Xue Bao. 2011;9:824-33.

21. Sunitha JD, Patel S, Madhusudan AS, Ravindra SV. An in vitro antimicrobial activity of few plant extracts on dental caries microorganisms. Int J Appl Pharm Sci Bio Med Sci. 2012;3:294-303.

22. Ramesh G, Nagarajappa R, Madhusudan AS, Sandesh N, Batra M, Sharma A, et al. Estimation of salivary and tongue coating $\mathrm{pH}$ on chewing household herbal leaves: A randomized controlled trial. Anc Sci Life. 2012;32:69-75.

23. Fullerton M, Khatiwada J, Johnson JU, Davis S, Williams LL. Determination of antimicrobial activity of sorrel (Hibiscus sabdariffa) on Escherichia coli O157:H7 isolated from food, veterinary, and clinical samples. J Med Food. 2011;14:950-6.

24. Nagarajappa R, Batra M, Sharda AJ, Asawa K, Sanadhya S, Daryani H, et al. Antimicrobial Effect of Jasminum grandiforum $\mathrm{L}$. and Hibiscus rosa-sinensis $\mathrm{L}$. Extracts against pathogenic oral microorganisms: An in vitro comparative study. Oral Health Prev Dent. 2013.

25. Agarwal P, Nagesh L, Murlikrishnan. Evaluation of the antimicrobial activity of various concentrations of Tulsi (Ocimum sanctum) extract against Streptococcus mutans: An in vitro study. Indian J Dent Res. 2010;21:357-9.

26. Asuquo BI, Montefiore D. Preliminary studies on the anti-bacterial properties of chewing sticks. J Dent. 1977;5:123-7.

27. George D, Bhat SS, Antony B. Comparative evaluation of the antimicrobial efficacy of Aloe vera tooth gel and two popular commercial toothpastes: An in vitro study. Gen Dent. 2009;57:238-41.

28. Haffajee AD, Yaskell T, Socransky SS. Antimicrobial effectiveness of an herbal mouthrinse compared with an essential oil and a chlorhexidine mouthrinse. J Am Dent Assoc. 2008;139:606-11.

29. Kumar U, Kumar K, Hindumathy CK. Study of antimicrobial activity of Rosa Indica against Gram-positive and Gram-negative microorganisms. Int J Microbiol Res. 2012;4:186-9. 